\title{
Library System Using Radio Frequency Identification (RFID) and Telegram Bot API
}

\author{
Dewa Agung Krishna Arimbawa $\mathrm{P}^{\mathrm{a} 1}$, I Ketut Gede Darma Putra ${ }^{\mathrm{a} 2}$, I Made Sukarsa ${ }^{\mathrm{a} 3}$ \\ ${ }^{a}$ Department of Information Technology, Faculty of Engineering, Udayana University \\ Bukit Jimbaran, Bali \\ 1dewaagungkrishnaarimbawap@gmail.com \\ 2 darma.putra@ee.unud.ac.id \\ ${ }^{3}$ sukarsa@unud.ac.id
}

\begin{abstract}
Libraries as a service provider to the user that needs fast, easy, and efficient services. Optimization of the services performed by the application of information technology such as utilizing barcode technology for the library system. Along with the development, there were some shortcomings in the use of barcode technology. Barcode technology can be replaced by RFID (Radio Frequency Identification) in order to further improve the operational and library services. RFID has some advantages over the barcode system is the possibility of data can be read automatically without regard to alignment readings, past the non conductor materials like cardboard paper with access speeds of several hundred tags per second at a distance of several meters. The advantages and capabilities of RFID can be applied in a library system in the inventory, self-service, and security so as to generate optimal library services more than manual systems or even a barcode system. Utilization of RFID technology in the library and then combined with technology Telegram Bot API as a medium to facilitate user access such as notification, accessing history, and others.
\end{abstract}

Keywords: library, RFID, Telegram Bot API.

\section{Introduction}

A library is a collection agency of writing, print, and/or professional record with a standard system to fulfill education, research, conservation, information, and recreation needs of readers [1]. Libraries as service providers need to provide services that are fast, easy, and efficient.

Computer-based information systems began to be applied in the library system as a step to improve library's services. Library information system developed using barcode system as identifier or book identity. Implementation of barcode system still had some weakness in addition to the emergence of new technologies, one of which is RFID (Radio Frequency Identification).

RFID systems have many differences compared to barcode systems that make RFID systems far superior in terms of capabilities it has [2]. 
Table 1. Comparison of RFID Systems with Barcode Systems

\begin{tabular}{|c|c|c|}
\hline Comparison & RFID & Barcode \\
\hline Line of Sight & Not Required & Required \\
\hline \multirow[t]{2}{*}{ Distance reading } & Passive: up to 10 meters & Several centimeters \\
\hline & Active: up to 30 meters & \\
\hline Read/write capability & $\begin{array}{l}\text { Can be read, written, and } \\
\text { updated }\end{array}$ & Only readable \\
\hline Technology & Radio Frequency & Optical \\
\hline Durability & High Endurance & $\begin{array}{l}\text { Low endurance. Easily } \\
\text { damaged, hard to read if } \\
\text { dirty }\end{array}$ \\
\hline Security & $\begin{array}{l}\text { Very secure. Data can be } \\
\text { encrypted }\end{array}$ & Low security. Easy to forge \\
\hline Automation & Does not require human & Require human \\
\hline
\end{tabular}

The ability of the RFID system can replace the barcode system that is currently widely used in library systems. I Putu Permana in research of Design of Pilkades System Using Smart Card Technology as Voter Card, using RFID-based smart card to identify the user so that it gives advantages that are security and accuracy of data of voter [3]. This system can serve as a guideline on the library system to identify library members in the process of circulation, book returns, tracking members, and library security system.

The RFID system applied to the library system is integrated with Telegram technology which is a free messaging app. Telegram provides a service called Telegram Bot API that allows other developers to create third-party applications. Telegram Bot API will be utilized in the library system as a notification media to members. In addition Telegram Bot API is used as a gateway for members to access some library related data. Ahmad Hanafi in Data Interchange Database Study by Using API Technology, applying request-response system using API on the database with an inbox-outbox concept, so the incoming data request in the inbox will be processed into response data entered in outbox table [4]. This concept can serve as a guideline for creating Telegram Gateway as another option for members to access data such as book lending history, book returns, book catalogs, and book bookings.

\section{Research methodology}

The research methodology used is the waterfall method contained in SDLC (Software Development Life Cycle), so that the research flow is done more structured. Here is the research flow used.

a. Defining the problem.

b. Data collection from literature study and observation

c. System design, database design, interface design.

d. Implementation.

e. Testing.

f. Conclusions and documentation.

\subsection{RFID System and Telegram Notification Overview}

The RFID system applied to the library system is integrated with the notification system via Telegram to library members. RFID system and Telegram notification overview are shown in Figure 1. 


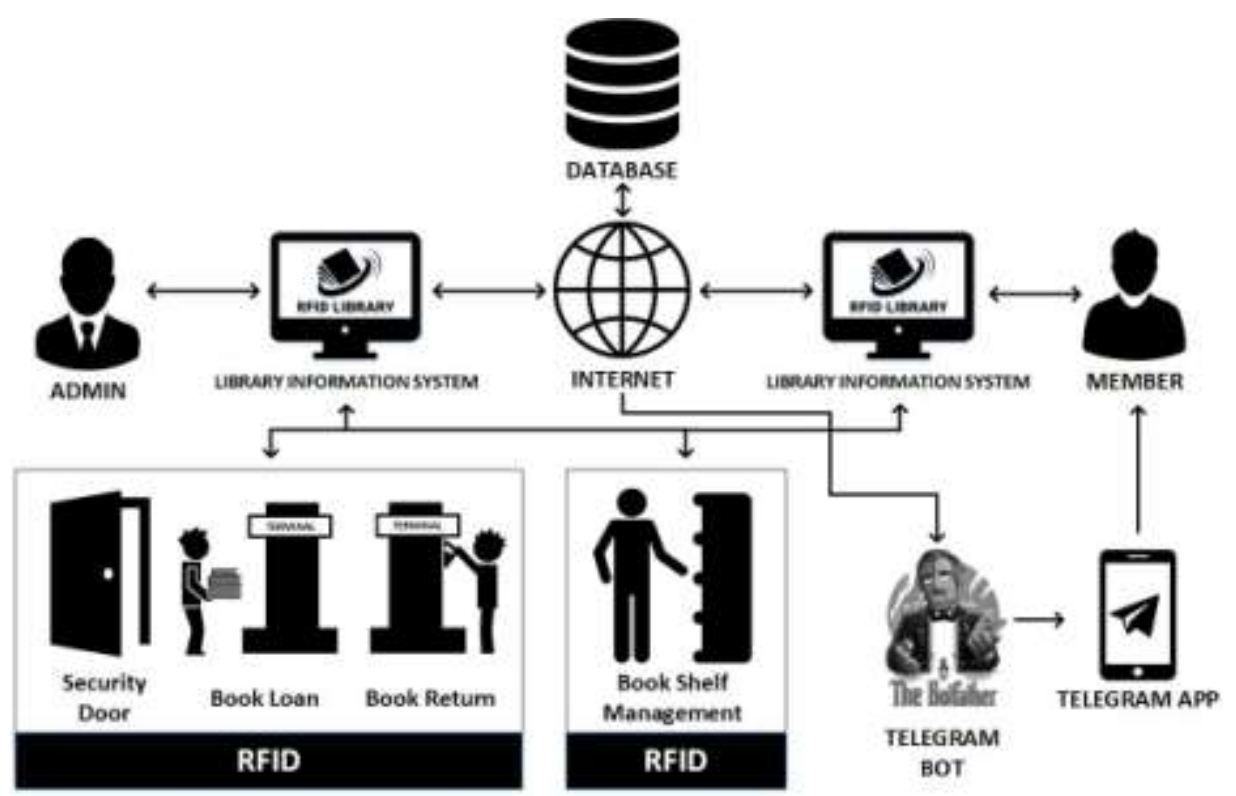

Figure 1. RFID System and Telegram Notification Overview

Figure 1 shows a general overview of RFID system implementation and Telegram notification on the library system. The application of the RFID system and Telegram notification are described as follows.

a. Door / Security

Members of libraries who already have a library member card (with RFID tags) will be detected by the RFID reader at the door after logging into the library. Detected member data will be directly inserted into the database (guestbook). There is also a security feature that is an alarm when someone carries a book out through a door without lending a book.

b. Book Loan Service

Book loan services can be done by library members at the book loan terminal. The process is done by scanning a member card then scanning the books to be borrowed.

c. Book Return Service

The book return service can be done by library members in the book return terminal. The process is done by scanning a member card then scanning the books to be returned.

d. Inventory / Tagging

The book of inventory process is done by attaching the RFID tag to the book which then the book data is entered into the system database.

e. Bookshelf Management Book

Bookshelves in the library are installed RFID, so book placement is appropriate to the category or fit on the correct shelf.

f. Member Notification

Members will get notifications of every process performed such as entry or exit of the room, borrowing, refund, due date, and booking. 


\subsection{Telegram Gateway Overview}

Telegram Bot system is used as a gateway for members to access some information such as loan history, return history, book catalog, and book order.

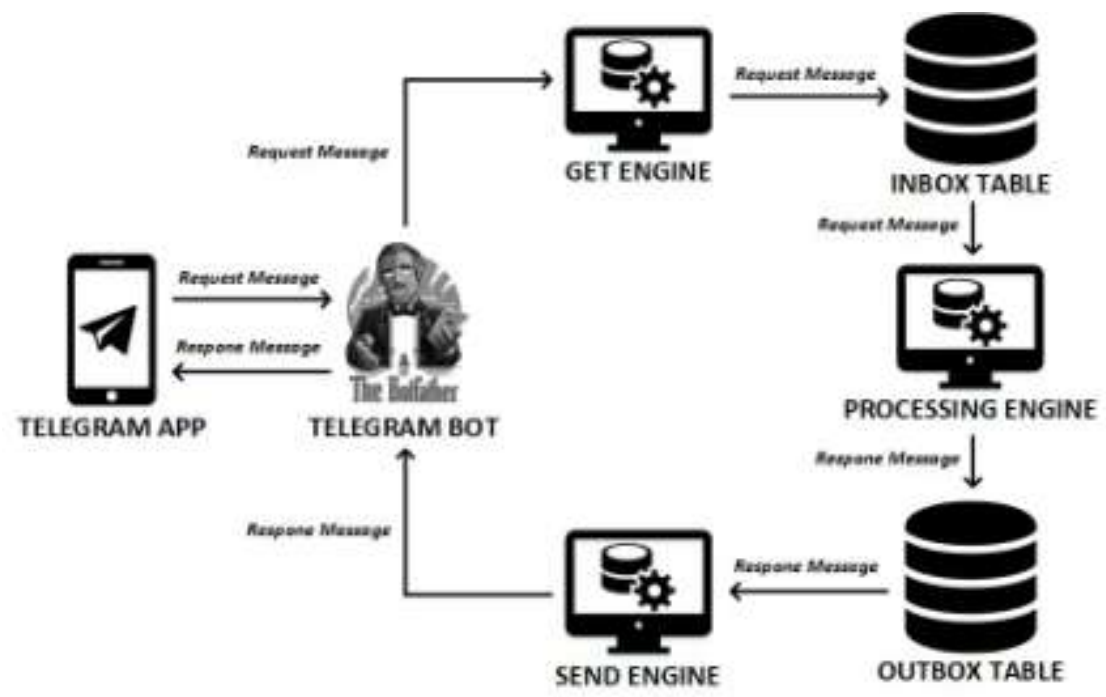

Figure 2. Telegram Gateway Overview

Figure 2 shows an overview of Telegram Bot implementation on the Telegram Gateway system on the member side. Members can use this Telegram Gateway system to access data such as loan history, return history, book catalogs, and book ordering. Telegram Gateway is a shortcut if you do not want to get into the library information system. Here is an explanation of the features of Telegram Gateway.

\section{a. Access book loan history}

Members can access the loan history through Telegram Messaging by sending messages to rfid_library_bot. Member can send a message "/menu" so that will emerge menu of the button, then the member can press the loan history button to get loan history data.

b. Access book return history

Members can access the return history through Telegram Messaging by sending messages to rfid_library_bot. Member can send a message "/menu" so that will emerge menu of the button, then the member can press the return history button to get return history data.

c. Access book catalog

Members can access the book catalog through Telegram Messaging by sending messages to rfid_library_bot. Member can send a message "/menu" so that will emerge menu of the button, then the member can press the search book catalog button. The Bot will reply with "Please type the title of the book to be searched ...", then the member must reply to the message with the title of the book to be searched. The bot will send the appropriate titles of books along with Book_ID. Members can download a catalog of books in PDF by sending a message format Download(space)Book_ID.

d. Book bookings

Members can place bookings through Telegram Messaging by sending messages to rfid_library_bot. Members can book by sending a message format Download(space)Book_ID. 


\subsection{RFID Reader Design}

Reader RFID dibangun dengan menggunakan microprocessor Raspberry $\mathrm{Pi}$, sensor RFID MFRC522, dan active buzzer.

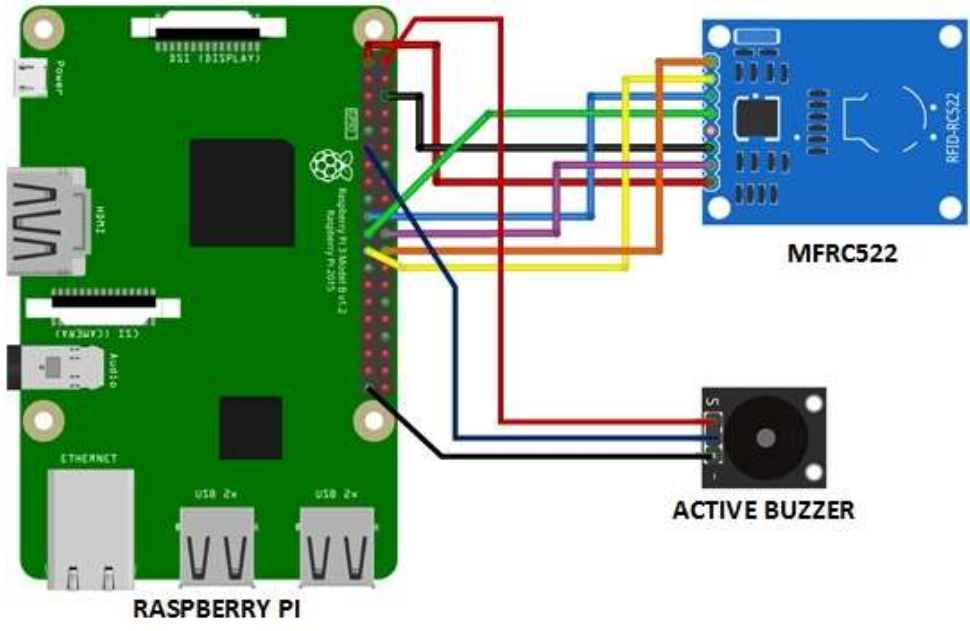

Figure 3. RFID Reader Design

\subsection{Physical Data Model (PDM)}

Physical Data Model (PDM) or relational database design Library System Using Radio Frequency Identification (RFID) and Telegram Bot API is shown in Figure 4.

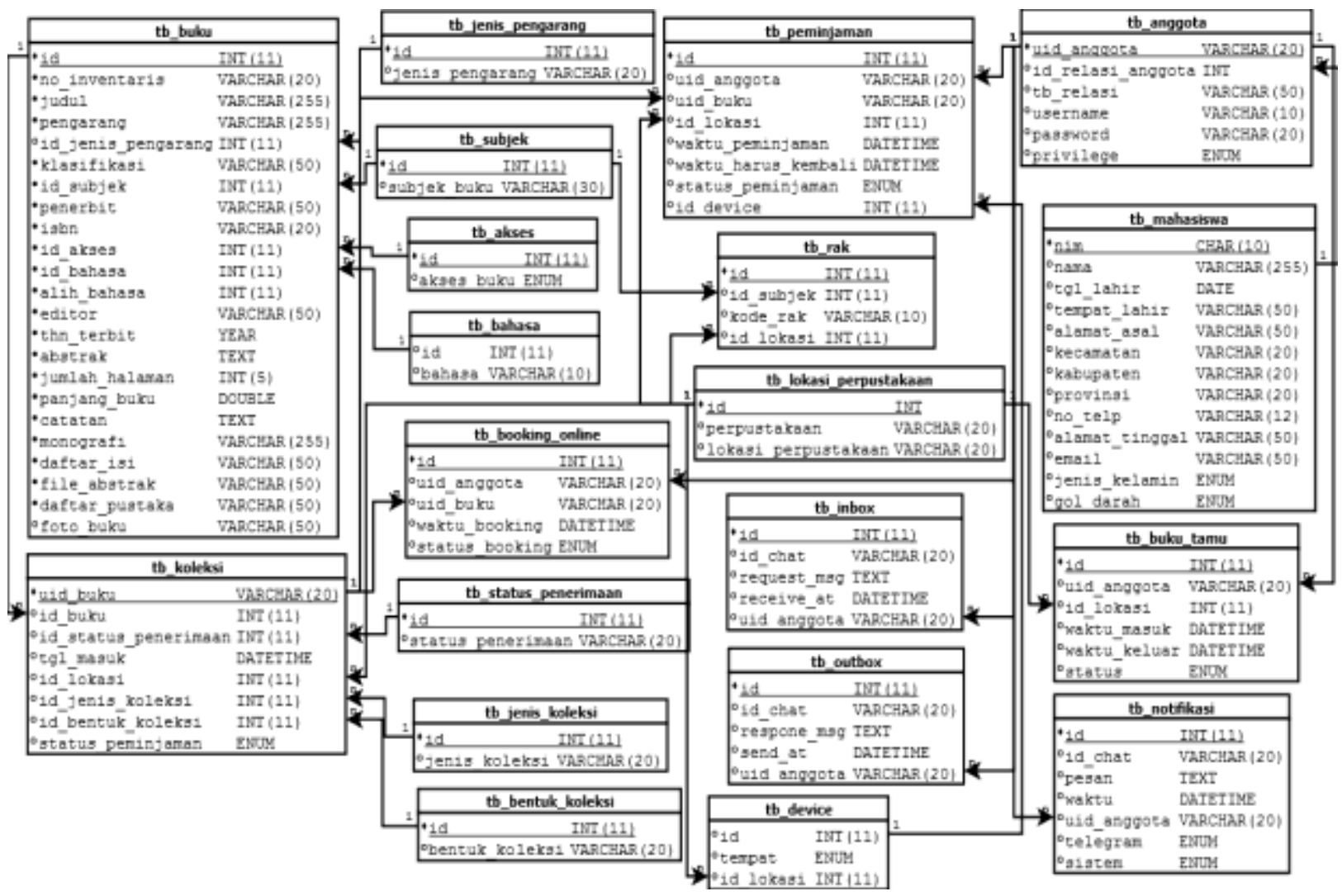

Figure 4. Physical Data Model (PDM) 


\section{Literature review}

Library review became a reference in the design of Library Systems Using Radio Frequency Identification (RFID) and Telegram Bot API.

\subsection{RFID (Radio Frequency Identification)}

Radio Frequency Identification or RFID is a wireless device that uses electromagnetic waves or radio waves to transfer data in order to identify and track tags on an object [5].

RFID standard has 3 main components. They are antenna or coil, transceiver or reader, and transponder or tag [6].

\section{a. Antenna}

The antenna transmits radio signals to read and write data into tags. It is the medium between tag and reader, which controls the data communication system Antenna is available in various shapes and sizes, can be installed inside the door to receive tag data from people or objects that pass through the door.

b. Transceiver or Reader

Transceiver or Reader is a device used to communicate with tags. The reader has one or more antennas, which emit radio waves and receive a reversal signal from the tag. Also called interrogators for interrogating tags.

C. Tag or transponder

RFID tags are microchips containing identities and antennas that transmit information to the reader. Basically the chips in the tag contain a unique identifier serial number.

RFID tags are generally divided into two categories: active tags and passive tags based on their power source [7].

a. Active Tag

The active tag has its own resources or has a battery that keeps the active tag sending a stronger signal, and the reader can access it further. The embedded battery makes the active tag larger and more expensive, so this system usually works best on remotely traced objects.

b. Passive Tag

Passive tags do not have battery power in them that make their size small and the price is affordable. However this causes the range of tag readings not so wide.

\subsection{MOM (Message Oriented Middleware)}

Message Oriented Middleware or MOM is an asynchronous message exchange mechanism that is widely applied to heterogeneous distributed systems. MOM provides applications in a distributed environment to send and receive messages [8].

Message Oriented Middleware is a middleware that provides a layer between high-level applications and platforms. MOM replaces direct communication between the parts involved in the message exchange system [9].

\section{Results and Discussion}

Results and discussion of Library System Using Radio Frequency Identification (RFID) and Telegram Bot API are described in the following processes. 


\subsection{RFID Reader Prototype}

RFID reader prototype is built using Raspberry Pi, MFRC522 sensor, and active buzzer.

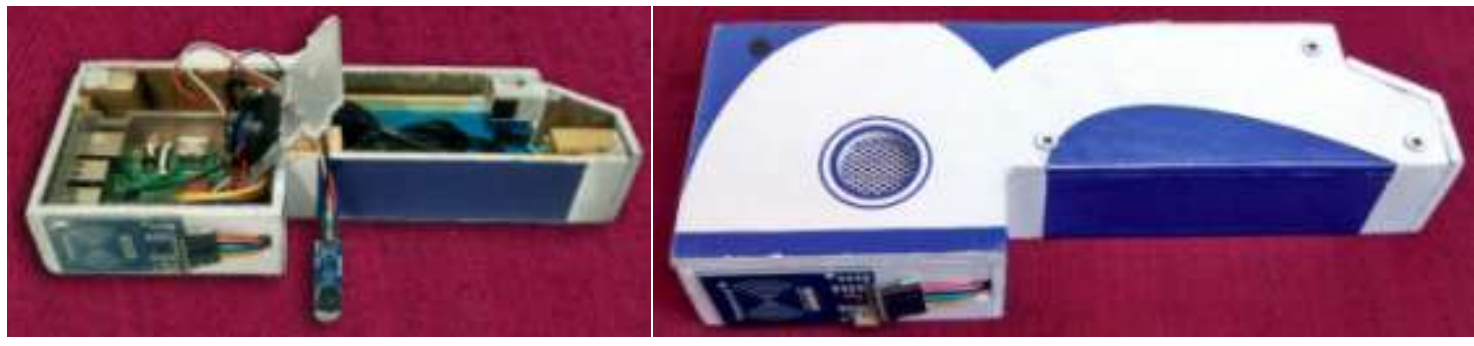

Fidure 5. RFID Reader Prototype

\subsection{Security Door Process}

The door is installed RFID reader so that it can read the member card to do tracking members and used as security against the books that come out of the library.

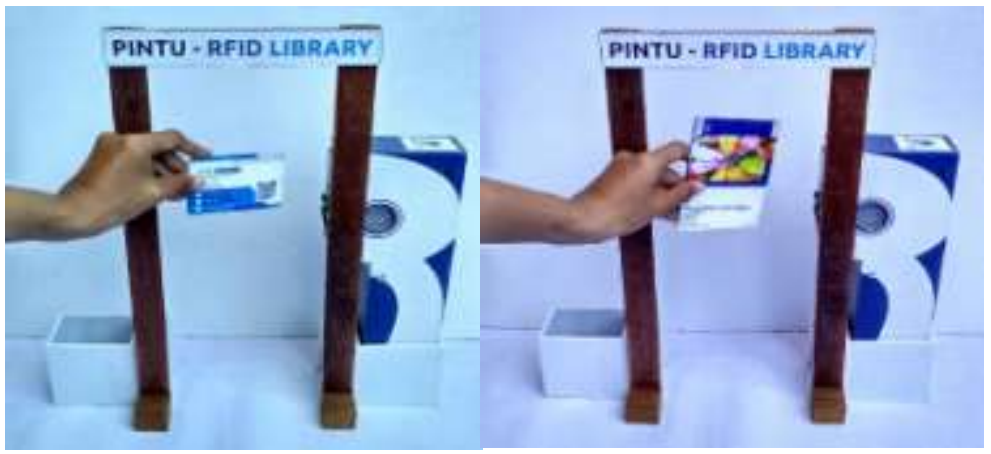

Figure 6. Security Door Process

Figure 6 is a process on the door where the RFID reader will read the membership card and book. If there is a book brought out without borrowing, the alarm will sound as a sign that there is a book brought out without permission. Reading of member cards on the door is a tracking and recording of visits. Members will also receive notifications from Telegram Bot when entering or leaving the library.

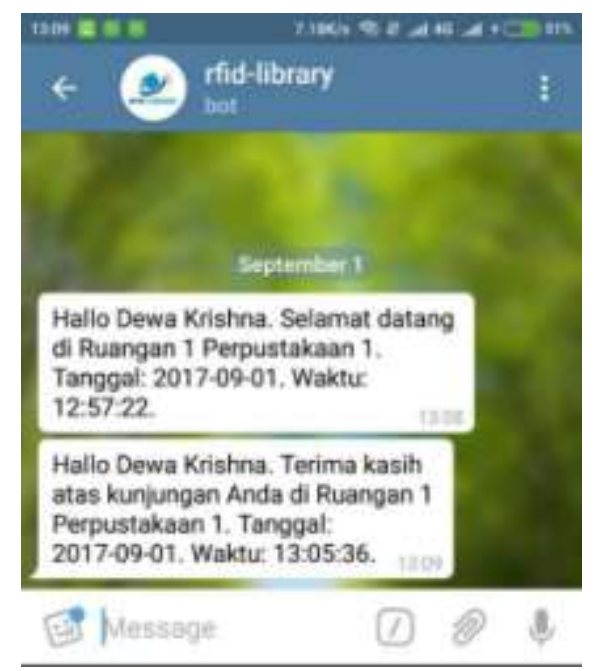

Figure 7. Member Notification When Logging Out or Entering The Library

Figure 7 shows that members will receive notifications via Telegram when members enter or exit the library. 


\subsection{Loan Process}

The loan process is done by members through the provided loan terminal. Members must perform member card scans in order to continue the loan process. After that will show a brief information about the borrowing history that has been done. When a member has borrowed as much as the maximum limit or there is a loan book that passes overdue, then the member can not do the loan again.

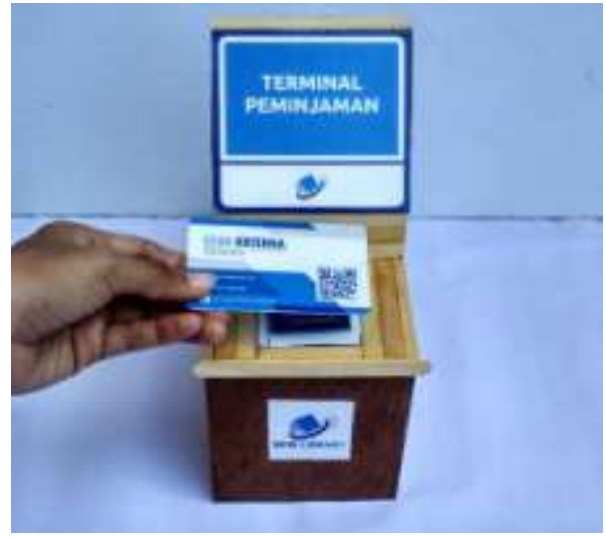

Figure 8. Member Card Scan at Loan Terminal

Figure 8 is the process of scanning the member card on the loan terminal and will display the information as in Figure 9.

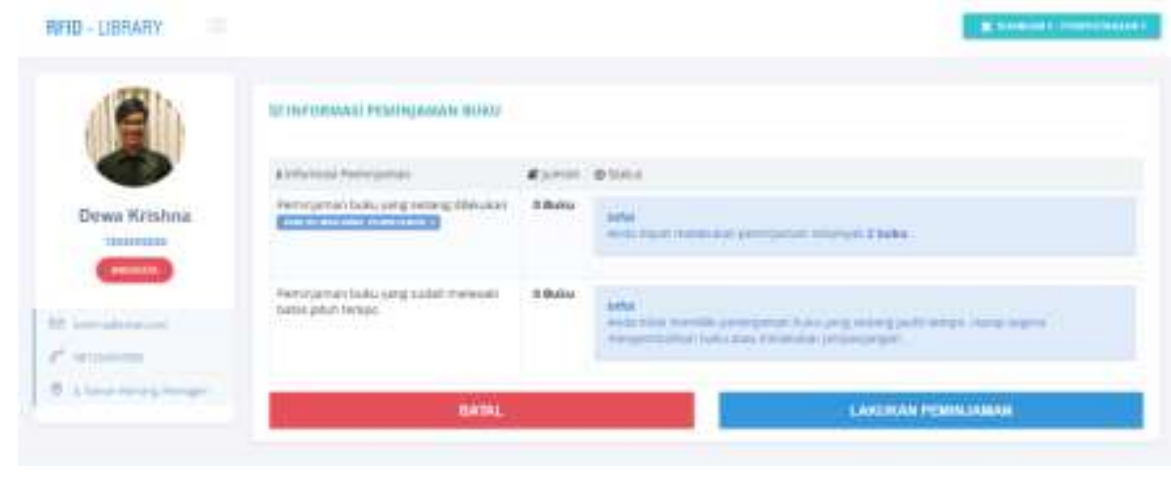

Figure 9. Information After Card Scan at Loan Terminal

After performing card scans the members can scan the books to be borrowed at the loan terminal.

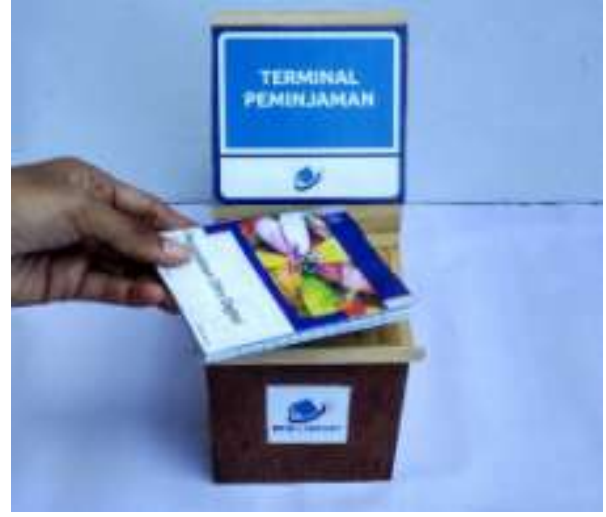

Figure 10. Scanning of Books Borrowed on Loan Terminals

After scanning the books to be borrowed, it will be on the borrowing terminal will look like Figure 11. 


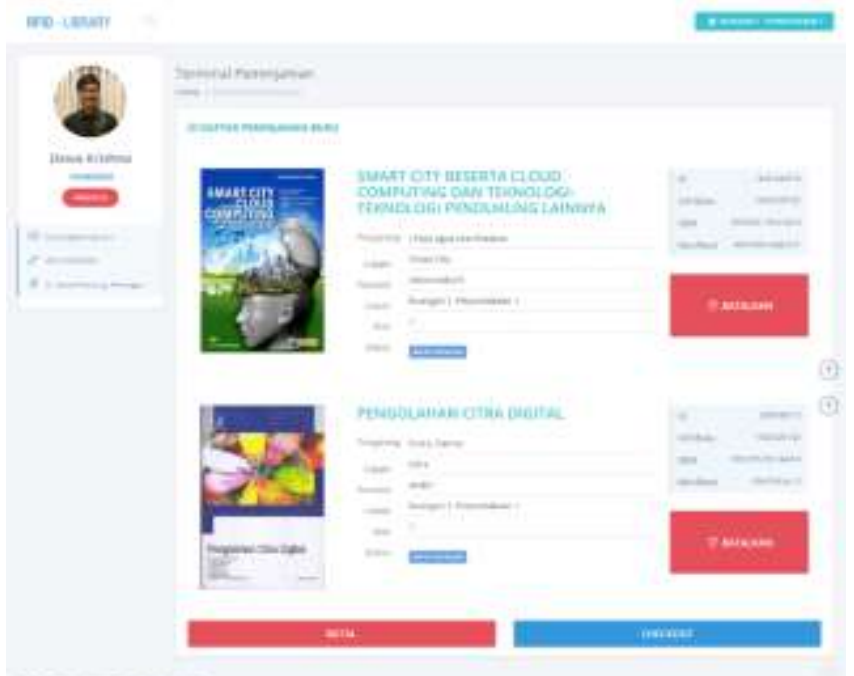

Figure 11. Scanning of Books Borrowed on Loan Terminals

Borrowing is continued by checking borrowing to display loan invoices made by members. Checkout of borrowing is shown as in Figure 12.

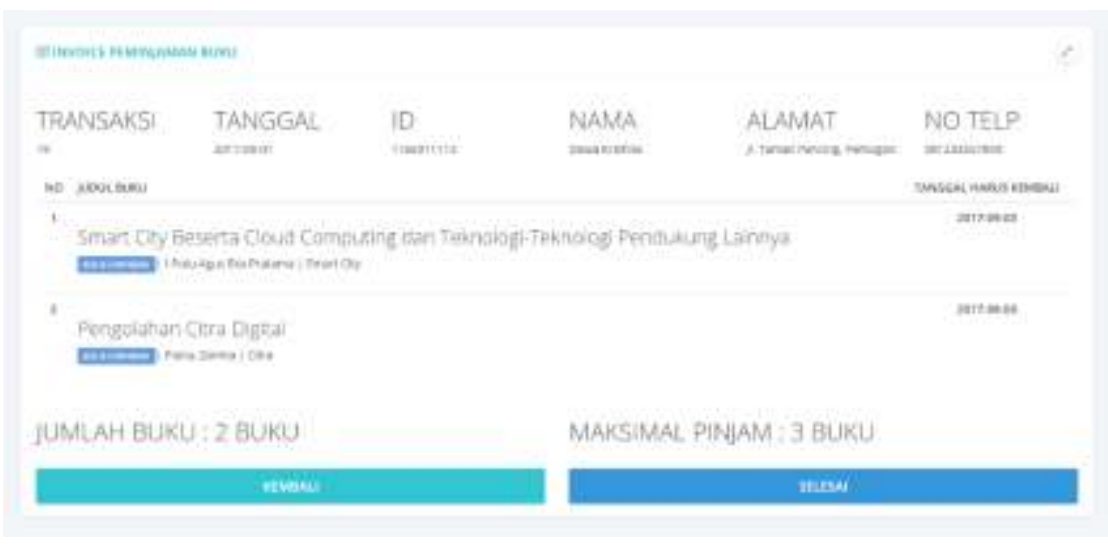

Figure 12. Loan Checkout

After the lending process is complete, members will get a loan notification through Telegram Bot.

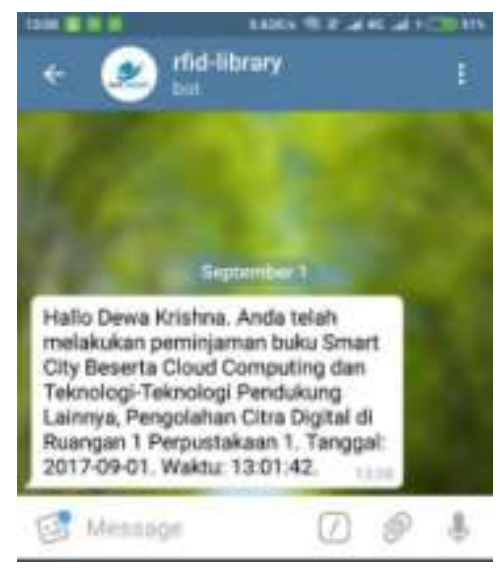

Figure 13. Loan Notification

Figure 13 is a notification that members get through Telegram after the lending process of the book. 


\subsection{Book Shelf Management}

Bookshelf management is a process undertaken by the librarian to check whether the books are in accordance with the category or in place. Officers must scan the RFID tags attached to the rack to be checked, information will appear on the books that should be on the shelf. Then the officer checks the books on the shelf. When the book is appropriate, it will appear in the column of the book by category. If there is a book that does not match then the RFID alarm reader will sound indicates there is a book that is not appropriate and will display information on the book does not fit the category.

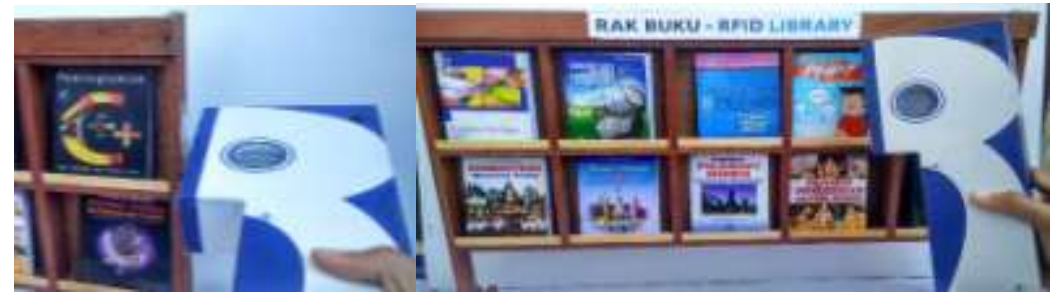

Figure 14. Book Shelf Management Process

Figure 14 shows the process of officers performing the examination of books on the shelf. The officer first performs a tag scan on the shelf, then scans the book.

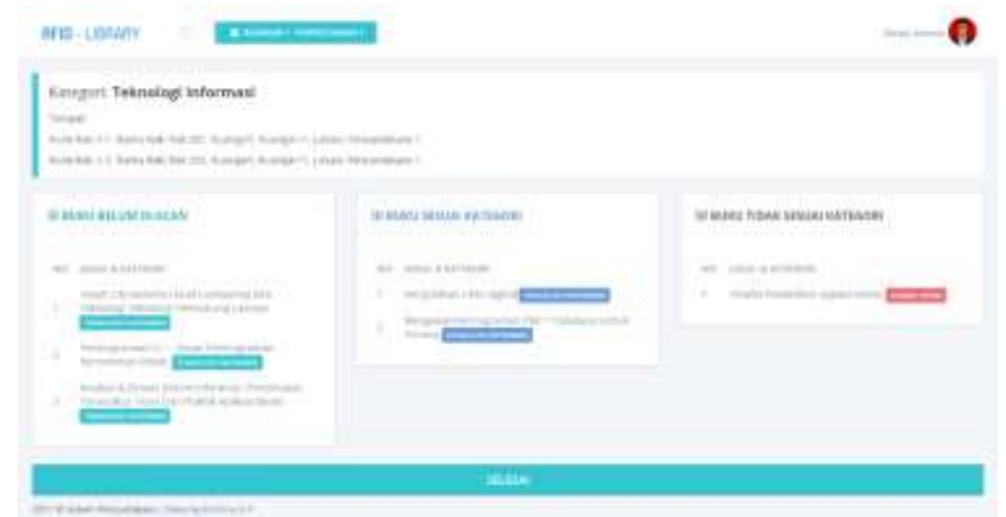

Figure 15. Book Shelf Management Process Information

Figure 15 is a display of book shelf management process. There is information about books that have not been scanned, books that are categorized, and books that do not fit the category.

\subsection{Telegram Gateway}

Telegram Gateway is an option that members can use to access some data such as lending history and so on only via Telegram.

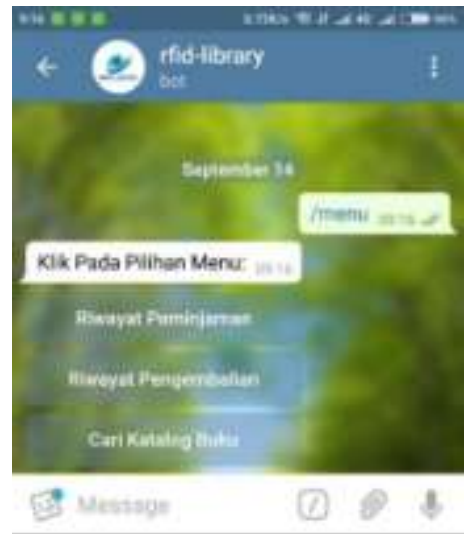

Figure 16. Command /menu Telegram Gateway 
Command /menu can be used to display the Telegram Gateway menu. When a member presses the Loan History menu then Telegram Gateway will send the member's loan history data.

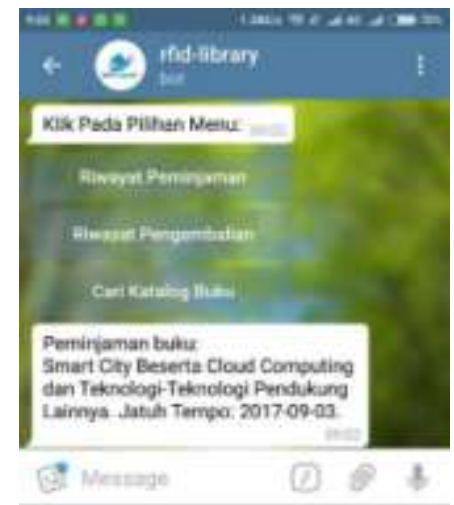

Figure 17. Result Telegram Gateway Loan History Menu

Members can press the loan history menu button to display a history of return as well as a borrowing history. Members can also search the book catalog by pressing the Find Book Catalog menu.
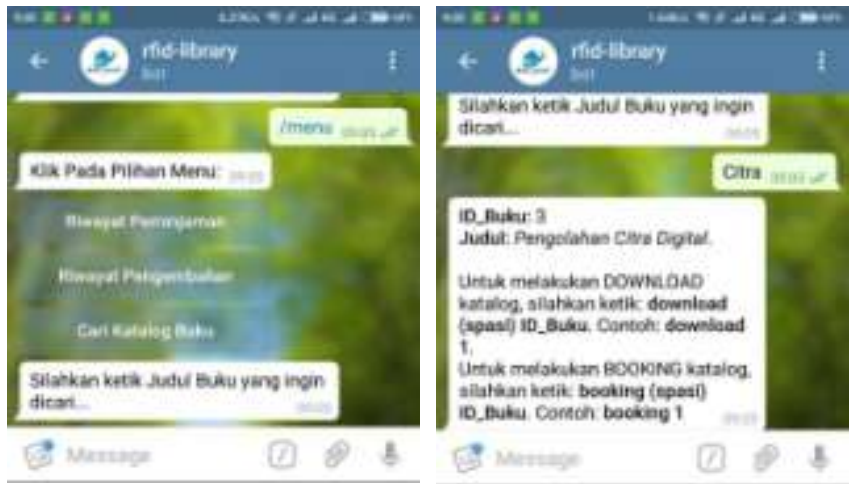

Figure 18. Results Find Book Catalog Telegram Gateway Menu

Members can download book catalogs and can book bookings by typing messages according to the rules exemplified in Figure 19.
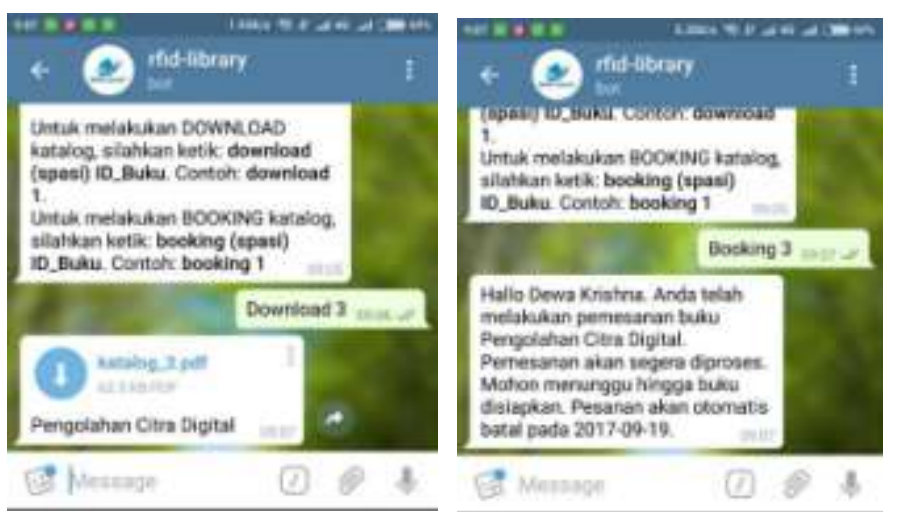

Figure 19. Download dan Booking Buku Telegram Gateway

\section{Conclusion}

Based on the research of the Library System Using Radio Frequency Identification (RFID) and Telegram Bot API which have been tested above, it can be concluded that the identification technology in the library system which currently still using barcode can be replaced with Radio Frequency Identification (RFID) which provides more benefits so that existing business processes in the library become more effective and efficient. Telegram Bot is implemented as a 
means of notification also presents an atmosphere of closeness between the library with members so that members feel served more by the library. Telegram Bot utilized as Telegram Gateway also becomes another option for members to be able to access information quickly without going through the login to the system but only need through Telegram application.

\section{References}

[1] Fajar Nugraha, "Analisa dan Perancangan Sistem Informasi Perpustakaan", SIMETRIS, vol. 5, no. 1, p. 27, 2014.

[2] Deepashree Mehendale and Reshma Masurekar, "A Comparative Study of Different Technologies for Electronic Toll Collection System", IJIRCCE, vol. 4, no. 2, p. 1537, 2016.

[3] I Putu I Permana, I Ketut G Darma Putra, and I Gusti M A Sasmita, "Rancang Bangun Sistem Pilkades Menggunakan Teknologi Smart Card Sebagai Kartu Pemilih", LONTAR KOMPUTER, vol. 7, no. 2, p. 87, 2016.

[4] Ahmad Hanafi, I Made Sukarsa, and A.A. Ketut Agung Cahyawan Wiranatha, "Pertukaran Data Antar Database dengan Menggunakan Teknologi API", LONTAR KOMPUTER, vol. 8, no. 1, p. 24, 2017.

[5] Nikhil Gudla, Sai Kalyan Paladagu, A Wahid Khan, and Raja Venkata Satya Phanindra Chava, "The Student Tracking Using RFID Technology", International Journal of Applied Engineering Research, vol. 11, no. 1, p. 174, 2016.

[6] Jayalakshmi $\mathrm{J}$ and Ambily O A, "Vehicle Tracking Using RFID", International Journal of Engineering Research and General Science, vol. 4, no. 2, p. 370, 2016.

[7] Trupti Lotlikar, Rohan Kankapurkar, Anand Parekar, and Akshay Mohite, "Comparative Study of Barcode, QR-code and RFID System", IJCTA, vol. 4, no. 5, p. 819, 2013.

[8] Lamia H. Khalid and Manal F. Younis, "Development of a Message-Oriented Middleware for a Heterogeneous Distributed Database Systems", Journal of Al-Nahrain University, vol. 14, no. 4, p. 235, 2013.

[9] Danilo H. F. Menezes, Marco T. Chella, and Hendrik T. Macedo, "A Client/Server Message Oriented Middleware for Mobile Robots", JOURNAL OF SOFTWARE, vol. 7, no. 45 p. 1156, 2012. 